\title{
Acting on Behalf of Another Without Consent as a Source of the Right of Obligations in the Republic of Kosovo
}

\author{
Ass. Prof. Dr. Sevdai Morina \\ University of Business and Technology, \\ Kosovo \\ Assoc. Prof. Dr. Endri Papajorgji \\ Dean, Faculty of Law, \\ Tirana Business University, \\ Albania
}

DOI: https://doi.org/10.36941/ajis-2021-o173

\begin{abstract}
In life, it often happens that humans take different actions on different occasions to save man or his wealth. These actions can be taken when there is a need to protect the integrity of man and his wealth, both individual and social wealth. Man performs these actions morally and without any institutional obligation. Man does the action without consent in order to save one's life or another's wealth. There is a need for such an action, because everyone sometimes in certain cases needs mutual help. With these behaviors of people, it is seen that they do not take these actions out of legal obligation, but act and should act with the consciousness and conscience of the civilized man. People who do this are driven by the need for cooperation, humanity, existence at the expense of the other, namely society. A person performs this action by perpetrating the work of another without consent for any other person. Hence, they undertake some factual and legal action for the other, sacrificing something that can be the property value and their bodily integrity. Sometimes this action must be taken because there are actions that cannot be postponed, therefore someone should take an action in such situations even when uninvited. Consequently, the subject matter analyzed in this paper is the act of perpetration of the work of another without consent as a source of the right of obligations in the Republic of Kosovo.
\end{abstract}

Keywords: work, without consent, gestor, principal, right, obligations

\section{Introduction}

There is a general and traditional rule that no one can do someone else's work. There are exceptions to this rule because in some cases it is allowed for a person to perform someone else's work with his actions. This should happen especially in situations when the action to be performed does not tolerate procrastination and must be performed urgently. The exception to the rule "that no one can do the work of another" derives from the legal obligation according to which every citizen must provide assistance to another citizen or society if the circumstances of the case allow it and require it. 
Committing such acts is also known as "acting on behalf of another without consent", which exists when a person performs legal or material work for another person. In these situations, the person who acts on behalf of the other is called the gestor (negotiorum gestor), while the person to whom the work is performed is called the principal (dominum negoti). Therefore, it often happens that when acting on behalf of another without consent, the gestor doing any work for the principal may have certain expenses or he may be harmed in any other way. Respectively, also for this reason in this situation the obligation must be established between the gestor and the principal. Such a thing is required by the rules of justice as well as other rules of cooperation, solidarity, interdependence and morality in society. Therefore, rightly, "acting on behalf of another without consent" is also a source of the right of obligations and is legally protected even in the provisions of the Law on Obligations of the Republic of Kosovo.

\section{Methodology}

In order to better study this issue, we have used mixed research methods. In addition, during the work on the topic, we have taken into account these factors:

- analyzed content of literature-based material;

- description and interpretation of relevant legal norms; and

- the use of these methods in the paper, such as: descriptive method, comparative method, analysis method, synthesis method and empirical method

Descriptive method - This method is used in this scientific paper related to the description of the problem that is the subject matter treated in this paper. This method has been used in this paper, because we have described the data related to the treatment of this topic. The main purpose of this method was to describe doctrinal opinions, legal provisions as they are and currently exist in our country. Comparative method - By means of the comparative method we have weighed the comparative elements, common features or differences that different authors have and the legislation related to the institute of acting on behalf of another without consent as a source of obligations in the Republic of Kosovo. Method of analysis - By means of this method we have unraveled the creative elements of thoughts, because this method is the approach of scientific research and explanation of truth through the unraveling of legal provisions and complex mental creations (meanings, judgments, legal provisions, conclusions) in the simplest elements and in integral parts of this material source of the law of obligations.

\section{Development and Understanding of the Institute of Acting on Behalf of Another Without Consent as a Source of the Right of Obligations}

The object of the law of obligations is the regulation of all civil legal relations that are related to the production, distribution, circulation of goods and products, related to the acts and services between legal persons, between legal and natural persons, as well as between the physical persons themselves (Tutulani-Semini, 2016). As we know, the material sources of obligations are those relevant legal facts, with which the relations of obligations can be established, changed and extinguished. These facts are: contracts, damage causing, unjust enrichment, doing the work of others and one-sided expression of will (Mustafaj, 2016). Rules for acting on behalf of another without consent, or without authorization are old rules of the law of obligations. These rules have been known since Roman law. Negotiorum gestio or incompetence to carry out acting on behalf of another was a quasicontractus (quasicontract), entered into by the negotiorum gestor (gestor) or the incompetent to carry out foreign affairs (unauthorized representatives) and dominus negoti (the principal) or persons whose work was done without prior agreement and without any legal obligation, on the initiative of negotiorum gestor, but which was useful for dominus negoti (Puhan, 1968). It is a fundamental example of a clear reasoning realization by which Roman jurists were able to harmonize law and 
social ethics with each other, more specifically, to balance the individual interest, not to confuse personal matters with the interests of society, to encouraged desirable ethical activities on behalf of others (Zimmerman, 1996). If negotiorum gestio had been restricted to owners who were not present, its scope would have been narrow, but in practice it could apply to many situations - whenever someone performed a certain service to someone (Borkowski \& Du Plessis, 2004). Thus, acting on behalf of another without consent constitutes a fact different from illegal facts as a source of obligations. This source of liability occurs when the holder is physically absent for various reasons. The basic feature of this institute is that we are dealing with undertaking the work or interests of another person, based on internal conviction, without being compelled. He is guided by the good intention of caring, to give active help to another who has left; e.g. repair of a wall collapsed by rain (Gjata, 2010). The perpetrator (performer) can perform the works or actions both in the name of the other person and in his own name (Galgano, 1999).

Therefore, from this right to the present law, the development and evolution of these rules has taken place. The idea for creating these rules has been in the rules of fairness, where the individual intervenes for the benefit of the other. Thus, intervening in acting on behalf of another without consent has the element of the subject that intervenes based on his personal will. This subject has no interest in this intervention, but has the good will to help the other (Alishani, 1989).

From this rule, the law of obligations also makes exceptions, in cases when the action to be performed cannot be delayed, or must be performed urgently, when there is a need to protect the integrity of man, or his property (Dauti, 2016). Ex. a person makes urgent repairs to the apartment of a neighbor who is not there or pays the funeral expenses of a deceased friend who has not left a will (Legier, 2008). Conducting an act without consent is about trespassing on another's property and protection of another's property without obtaining prior authorization from the holder of that property. Doing the work of another or an activity for the benefit of another person, without their consent, is a legal relationship of obligation that arises from the fact that, someone, without being commissioned, ie, without being authorized, performs certain activity for the benefit or in the interest of another (Gjata, 2010).

These rules regarding this source of the law of obligations, the Law on Obligations (LO) provides from Article 203 to Article 211. The LCT explicitly provides for this source of obligations that "a foreign job can be performed without order only if the act to be conducted cannot be procrastinated and damage may be caused or a benefit can be clearly lost" (Law on Obligations, Article 203). Also, the Civil Code in the Republic of Albania (KCSH) stipulates that "A person who, without being obliged, conscientiously undertakes and for a reasonable purpose to carry out the work or interests of another, is obliged to continue it until the interested person is able to take care of himself" (KCSH, article 648). According to these legal provisions, this is allowed when the preconditions are met, for the work to be allowed and not personal. Regarding the permissibility of another's work, it can be performed without consent only when the work cannot be postponed and there is a possibility of causing damage or loss of an obvious benefit (Berisha, 2013).

The most important fact we need to emphasize is that the action must be well-intentioned, based on objective assessment, to prevent the loss of any benefit of the principal (Berisha, 2013). Referring to this source, obligatory relations are created between the conductor of the works (negotiorum gestor) and the principal (dominius negoti). Thus, the gestor is the subject who performs the work for the other without his consent and appears in the position of creditor, who has the right to demand from the principal (dominius negoti), that is in the position of the debtor in thiscase, to pay the expenses for the work conducted to his benefit (Dauti, 2016).

\subsection{The terminology of this source of the law of obligations}

The terminology for naming this source of law is not unique in the doctrine, the laws and the case law, both in our law and in comparative law. If the terms used in this source of the law of obligations are carefully examined, it is easy to see that there are used other terms that can be understood in 
different ways too. The terminology should always be designated, taking into account the essence of the institution, the nature of language and traditionalism in terminology, as well as the fact how a group understands the given term (Alishani, 1989).

In comparative law, the term "acting on behalf of another without consent" is used / doing the work of another $\backslash$ (Sallabanda, 1961). The first term for this source is not a precise and adequate term. It is not a precise term, because the term acting has a broad meaning and is not indicative of the performance of legal work for the benefit of another person without consent. Meanwhile, the term doing the work of another is more appropriate for naming this source of the right of obligations, because it indicates doing the work of another. However, this expression lacks the expression without consent, so with the addition of this expression an element of this source will be completed, that someone does the work without consent, without authorization and without invitation. Also, in the doctrine, laws and case laws, the term "uninvited performance of another's work" is used. This term is apt because it contains the essence of the work in this area. It is said so because this shows the performance of one job, the performance of the work of another, a work that is performed without consent, without authorization and without invitation. Therefore, if this term is used it is not wrong (Alishani, 1989).

In French doctrine, law, and case law, the term "gestion d'affaires" is used. This term apparently is not apt. It is said so, because the term management does not indicate who manages, the way he manages, whose affairs are managed, and so on. These are facts relevant to the expansion of custom foreign affairs. It is understood that in the analysis of these rules it is clear that in this case we are dealing with the conduction of another's work without consent, however, the term used is somehow not indicative of these elements that define the features of this source of law of obligations (Alishani, 1989). In addition, the term "work without consent" is used. This label is quite apt because it indicates the conduction of a job without an order. Since it is worth mentioning here that this term does not include the element that another's work is performed, which is important, because it is a condition for the conduction of another's work that the work be performed at the expense of another. The term "conducting another's work" is also used in the literature. This label is apt as long as it indicates that another's work is being done. However, this term lacks the term without consent, without authorization or without invitation (Alishani, 1989).

Finally, it is worth mentioning the fact that the use of the expression "acting on behalf of another without consent" is a name that includes all the conditions for the existence of this resource, therefore it should be supported and we will continue to use, in this paper, the terminology "acting on behalf of another without consent".

\section{Conditions that Must be Met for the Existence of the Obligation to Act on Behalf of Another Without Consent}

In order for foreign works to be performed without consent, the following conditions must be met: there must be conduction of work, another's work must be conducted and work must be conducted without authorization (Dauti, 2016).

\subsection{The work must be done}

In order for this source of the law of obligations to exist, the main condition is for the work to be conducted, because if the work is not conducted, then the obligation to perform foreign works without consent does not arise either. In addition, the work to be performed must be performed directly by the gestor. The work performed can be legal (entering into a contract or purchasing an item for the pricipal). The work can also be factual, e.g., to offer the necessary help to the other, to save the other's property from fire, floods, etc. In addition, "another's work can be done without consent only if the job cannot be procrastinated and can cause harm or clearly lose a benefit" (LMD, Article 203). In any case, there must be some active, positive action because by inaction or abstention 
cannot be created the obligation to perform foreign affairs without order within the law of obligations (Dauti, 2016).

\subsection{The work perpetrated belongs to another (negotium alienum)}

The other condition for the existence of the obligation to perform foreign works without consent is that the action or work performed is really foreign. The uninvited gestor must have the awareness and the intention to conduct the action on behalf of another (Loza, 1978). In legal theory, a distinction is made between foreign works in the objective and subjective sense. In the objective sense, they are treated as foreign works, for example, when a subject pays the bill for the electricity consumed by the neighbor who is not at home, or has repaired the broken water pipe in the neighbor's apartment. In the subjective sense, another's works are those which by nature are neutral, but are classified as acting on behalf of another without consent given the orientation of the will of the gestor (Radisic, 1980). The contractor by his action must maintain or increase the wealth of the principal, because he by his action must benefit the material values of the principal or foreign property. In this condition, the will of the gestor is important for him to conduct work on the behalf of the principal, e.g., when the contractor repairs the burst pipe to his neighbor, or when he extinguishes the fire in the foreign house (Alishani, 1989) without the presence of the owner of the house. Therefore, the action taken should be done for the sake of protecting the interests of another, a relationship that the action of the gestor benefits the foreign property (Dauti, 2016).

\subsection{The work must be conducted without authorization (without consent)}

The third condition to be doing the work of another without consent, is the work or action taken by the principal, that it be performed without the authorization provided by law, contract or court decision (Dauti, 2016). Animus obligandi exists at the moment when the contractor interferes in the affairs of the principal (Alishani, 1989). So, in order for the work of another to be done without authorization to exist, the gestor of works without authorization must have indeed undertaken the conduction of foreign works; that the work be another's; that the work has been performed for the purpose of protecting the interest of another and that the contractor is not authorized by law, by contract or in any other way to perform these actions (Vokshi, 2015). In those cases where there is authorization, there would be representation as a specific legal institution for which there are special rules (Dauti, 2008).

\section{Legal Effects of Acting on Behalf of Another Without Consent}

Certain legal effects this source of compulsory law is expressed: in the rights and duties of the gestor acting on behalf of another without consent and of the principal.

\subsection{Duties and rights of the person acting on behalf of another without consent (negotiorum gestor)}

Carrying out the work of another can be done in different situations. Only if the foreseen legal conditions are met between the gestor and the principal, a legal relationship is created from which rights and duties arise for both parties (Berisha, 2013). Therefore, in order for the obligation to arise from carrying out the work of another without consent, certain conditions must be met, such as; the gestor performs work, legal action or other actions for the other; the work or interest must be foreign; the work or action may be performed for the benefit of the principal; the gestor must act without consent. The rights and obligations of the parties are regulated according to the type of activity. However, in any case, the person who has undertaken a work or legal action without being authorized, must while performing the work, act with the care and awareness of a regular and careful person (Gjata, 2010). These duties and mutual rights of this source of obligations are also provided in 
the legal provisions of the Law on Obligations (LMD). Given the fact that the gestor is the person who has taken the initiative from which this obligatory relationship between him and the principal has arisen, the law first provides for his obligations towards the latter and then his rights (Berisha, 2013). Thus, according to the law in Kosovo, the person acting on behalf of another without his consent has the duty to inform the employer about his action as soon as possible and to inform him that he will carry out the work, if there is a reasonable possibility, until the principal can take over the care of it. Upon completion of the work, the gestor has the duty to give an account and transfer to him all that he has gained from the performance of the work. Unless otherwise provided by law, the person acting on behalf of another without consent has the obligation of the ordering party (Law on Obligations, article 204, parag. 1, 2, 3).

Article 204 of the Law on Obligations provides for the obligations of the conductor without consent to the principal. While the action has been taken for a certain purpose, in order for the principal to undertake everything necessary to protect his interests that may have been endangered by the intervention of the gestor, according to this legal provision, the gestor has the obligation, depending on the circumstances of the case, to notify the employer as soon as possible (Berisha, 2013). It may happen that there is no possibility to notify the principal and this happens in the case when the gestor does not know who is the person whose work he is doing or he is not there for a while. In such cases, the work started must be continued, fulfilling all the obligations he has as a performer of foreign works without consent. Failure to notify in time can have an impact on the decision regarding the remuneration of the work performed or any eventual damage caused during the performance of work without consent (Berisha, 2013).

The Law on Obligations also in the legal provisions for the regulation of this source of obligations foresees the duty of due care and the responsibility of the person perpetrating the work of another without consent. This law expressly provides that: "During the perpetrating of the work of another, the perpetrator has the duty to be guided by the factual or presumed goals of the principal. He has a duty to act with the care of a good economist. The court may, taking into account the circumstances in which someone started the foreign work without being summoned, reduce his / her liability or release him / her from liability for negligence (Law on Obligations, article 205, paragraphs $1,2,3)$. The first paragraph of this article, regarding care at work, defines the necessary manner of conduct of the perpetrator of foreign affairs. In this aspect, the perpetrator of another's work without consent, while performing another's work is obliged to be guided by the real or supposed goals of the principal. Given the fact that it is about the existing or presumed purpose of the other person, the problem in itself is the meaning of such a purpose and whether it is right or not to ascertain the gestor regarding the purpose of the principal (Berisha, 2013). The contractor is obliged to submit a report on the work he has performed, e.g., to submit the bill on the payment of electricity, as well as to carry in full what he has accomplished from the work performed, e.g. items, money, etc. (Dauti, 2016). The gestor also has certain rights. The rights of the perpetrator of another's work without consent are foreseen in the legal provisions of the Law on Obligations, which stipulates that: The perpetrator of the work of another without his consent, has the right to request from the principal to be released from all the obligations he has undertaken due to this work, to take upon himself all the obligations he has entered into on his behalf, to be rewarded for all necessary expenses, even if the expected result is not achieved. The perpetrator of the work of another without his consent, is also entitled to an adequate reward for the effort, if he has avoided the damage from the principal, or if he has provided the benefit that fully corresponds to his goals and needs (LMD, article 206, paragraph 1.2).

In Roman law, the duties of the person performing the service of the gestor, was to fulfill what he had begun, and to justify any kind of gain or loss. He was responsible for negligence in the performance of the service and he was required, the implementation of the bonus standard paterfamilias. However, if the gestor had acted in an emergency, he was solely responsible for the dolus. But if the loss was caused by an action that the principal would not have done, the gestor was strictly responsible, yet he could compensate the losses despite the benefits of unauthorized actions 
(Borkowski \& Du Plessis, 2004).

\subsection{Obligations of the principal (dominus negotti)}

The principal (dominus negotti) has the duty: to pay all useful and necessary expenses; to compensate the gestor for the actions he has taken or has performed on his own behalf and to compensate the damage in case the gestor has suffered a certain damage (Dauti, 2016). All these liabilities, expenses of damages must be paid, until the perpetrator is prohibited from continuing to perform work and actions by the principal. The interested person will respond to the perpetrator when the latter has performed work or actions in his favor without his consent (request) and without being stopped by him. It does not matter whether he was aware or not, but the moment the interested party (principal) orders the cessation of works or activity, the perpetrator is obliged to stop (Gjata, 2010). Regarding the obligations that are created for the principal towards the perpetrator of another's work without consent, it is important to understand that the respondents can be both natural and legal persons, whether private or public, as well as the state. The principal ratifies the work of the perpetrator, it is considered that this ratification was done voluntarily and has a retroactive effect (Dauti, 2016).

\subsection{Ratification}

The Law on Obligations stipulates, "If the principal later approves the work that has been done, the perpetrator is considered as the order recipient who has worked from the beginning by request of the principal" (Law on Obligations, Article 211). Therefore, if the principal (dominus negoti) ratifies the work of the perpetrator (negotiorum gestor), we can state that this ratification was done voluntarily and has a retroactive effect. It is understood that the principal ratifies the work, respectively the action from which he benefits, and not in the case when there is no benefit (Alishani, 1989). Despite the responsibility of the perpetrator, as described above, such actions violate the interests of the principal (Berisha, 2013). Instead of exercising his rights under the law, in situations where the legal relationship of the principal cannot be established without an order, in order to protect his own interests, the person in whose work someone has interfered without authorization, according to Article 211 of the Law on Obligations, may meanwhile approve later what has happened in the case of carrying out his works without authorization. Pursuant to this legal provision, in the case when the principal, meanwhile later approves the work performed, the gestor receives the title and is considered as the employee who has worked, from the beginning by order of the principal. With this act and in this way the relations between them are resolved based on legal provisions, which regulate the contract for the order (Berisha, 2013).

\section{Legal Nature of Acting on Behalf of Someone Without Consent}

There are different opinions on the legal nature of this source of liabilities. The older opinion equates doing custom foreign work with ready-made contracts (quasi contractus). This opinion is represented especially in French law. According to this right, acting on behalf of another without consent, creates relations similar to the relations from contracts. This opinion is also derived from Roman law (Milosevic, 1977). The second opinion denies the existence of ready-made contracts (quasi contractus) and equates acting on behalf of another without consent with the authorization contract. According to this opinion, the person acting on behalf of another without consent has a position similar to the position of the authorized person, while the principal has a similar position of the authorizer. The only difference is that in the contract of authorization there is an agreement of the expressed will of both persons, when acting on behalf of another without consent there is no such agreement, but that the person acting on behalf of another without consent is voluntarily obliged to perform foreign work, which benefits the principal. The third opinion considers that acting on behalf 
of another without consent as a source of obligations represents the one-sided legal work, as is the case with the public promise of the gift and the giving of the payment to the bearer (Milosevic, 1977). In German legal theory a fourth view has been pointed out, according to which acting on behalf of another without consent as a source of obligations represents the real act, which is similar to legal work, but still not legal work.

Therefore, as a fair opinion can be applied that "acting on behalf of another without consent" represents a legal institute of its kind, which cannot be equated with any institute that now exists. The relationship of obligations which is created between the principal and the gestor of customary legal work has its own special properties and characteristics, so it is fairer to be divided into a separate legal institute (Milosevic, 1977). This opinion is the fairest in legal doctrine.

\section{Types of Acting on Behalf of Another Without Consent}

There are several types of perpetuating the work of another. They are the necessary perpetration of the work of another without consent, perpetrating of the work of another without consent must be beneficial and the prohibited perpetration of the work of another without consent.

\subsection{Necessary perpetration of the work of another without consent (negotiorum gestio necesaria)}

The necessary perpetration of the work of another without consent is when the perpetrator of the work of another without consent undertakes actions to avoid the direct damage that threatens to another subject or his property, e.g., extinguishes the fire, when he takes action to repair the water pipe that has burst in the foreign house. In this case of perpetrating, the principal has these duties towards the contractor, to pay the reasonable and necessary expenses he has incurred in performing the work and to pay the loss of personal income in case that he has lost them (Dauti, 2016). This type of perpetrating (negotiorum gestio necessaria) exists if a person interferes in foreign work to avoid harm, which threatens to strike at the life, health or property of another person who is in need. Therefore, necessity is an essential fact in this case of perpetration of the work of another without consent because this justifies the undertaking of action for the other. In the case of the necessary perpetration of the work of another without consent, it does not matter whether the perpetrator of the work of another without consent has succeeded with his action. The main thing is that there was a need to take such an action and that the perpetrator of the work of another without consent worked consciously, even if he would not achieve a certain success (Milosevic, 1977).

\subsection{Beneficial perpetrating of the work of another without consent (negotiorum gestio utilis)}

This case is when perpetration of the work of another was not necessary, but nevertheless brought benefits to the principal, e.g., when the perpetrator buys for the principal any item at a very affordable price. The gestor must, by his action, succeed in contributing to the increase of the wealth of the principal. The benefits should be clear and obvious. In case there is a benefit from the work done, the principal has the duty to pay to the perpetrator all costs for the work undertaken as well as to the necessary perpetration of the work of another without consent (Dauti, 2016). In this type of foreign work performed by order, the perpetrator of the work of another without consent must with his action be successful (to increase the wealth of the principal). The usefulness of the work is assessed from the point of view of the principal, and not from the gestor's point of view. The benefits of the act should be clear and obvious. Here there is great risk for persons who take action for the other, because the benefit must really exist and be greater than the costs incurred (Milosevic, 1977). 


\subsection{Prohibited perpetration of the work of another without consent (negotiorum gestio in utilis, negotiorum gestio contra voluntate domini negotii)}

This case exists when the perpetrator takes any action for the principal even though there is a prohibition by the principal to not carry out that action (Alishani, 1989). The case of prohibited perpetration of the work of another without consent is foreseen in the Law of Obligations, where it is stipulated that: Whoever perpetrates the work of another despite the prohibition of the principal, and was or should have been aware of the prohibition, does not have the rights that belong to the perpetrator of the work of another without consent. He is responsible for the damage he has caused by interfering in another's work, even when it has come about through no fault of his own. When the prohibition to perform work is contrary to law or morality, especially if one has prevented the other from fulfilling any of his legal obligations that cannot be postponed, the general rules for the perpetration of the work of another without consent apply "(Law on Obligations, article 209, Para. 1, 2, 3). Article 209 of the Law on Obligations regulates the perpetration of the work of another, despite the prohibition by the principal. According to this legal provision, the one who perpetrates the work of another despite the prohibition by the principal does not have the rights that belong to the perpetrator of the work of another without consent. The principal can stop before the work starts or after it has started, respectively after receiving the notification for the start of work from the principal. In order to lose the rights that belong to him, it is necessary for the contractor to be or should have been notified of this prohibition. It follows that the contractor could have been notified of the prohibition directly by the employer or, according to the existing circumstances, should have been aware of this prohibition (Berisha, 2013). Also, according to this sub-responsible for compensation of damage is the person for whose fault the damage was caused, respectively the person who is responsible for his actions. However, law does not allow any prohibition, so even a prohibition given by the principal may be contrary to law or morality. Thus, in case of danger to life, no matter how much one opposes the other to help him save his life, he is, by law, obliged to take certain actions to save his life, moreover, if he does not take appropriate aid actions, he is criminally liable, which means that this is also his legal obligation. Therefore, in such cases, when the prohibition of the employer is contrary to law or morality, especially if it prohibits the other to fulfill a legal obligation that does not tolerate procrastination, it does not oblige the contractor to act according to the order; despite the existence of the prohibition of the employer, the general rules for the perpetration of the work of another without consent apply (Berisha, 2013). In this case, the essential fact is the existence of a ban on interference in the work of another. Perpetration of the work of another without consent, e.g., when someone offers him maintenance even though he is not obliged by law to maintain it. If this case exists for the employer, no duties exist (Dauti, 2016).

\subsection{Illegal perpetration of the work of another without consent}

Perpetration of the work of another without consent exists when the perpetrator performs the work of the employer in order to stop the benefits created for himself, even though he knew that it is another's work. This is the case when someone rents another's property, when he uses another's apartment without authorization, when the perpetration intentionally takes on the wok of another and uses it to benefit him, even though he knows that he is not authorized to do so (Radisic, 1980). In this type, the perpetrator behaves and acts in bad faith. In the case of the expansion of foreign affairs without order, Law on Obligations in its provisions stipulates that "Whoever perpetrates the work of another in order to keep the benefits achieved, even though he knows that the work is not his, has a duty at the request of the principal to give account as a manager without order and to hand over all the benefits achieved. The employer can claim the return to the previous condition as well as the compensation of the damage (Law on Obligations, article 210, para. 1, 2). Thus, Article 210 of the Law on Obligations contains provisions on unauthorized intercession for personal gain, which represents an unfair perpetration. According to parag. 1 of this article, the one who perpetrates the work of 
another in order to keep for himself the benefits achieved from that work and not for the above mentioned legal reasons, according to the request of the employer, has the obligation to give an account as a manager without consent for all the completed work. At the same time, he has the obligation to hand over to the employer all the benefits achieved from that work without order. In order to have these obligations, the gestor must have known that the work is another's (Berisha, 2013).

\section{Similarities and Differences of Acting on Behalf of Another Without Consent According to Some Other Institutes}

The perpetration of works and actions for the benefit or interest of the other, as an institute in itself, distinguished from other institutes that are similar to it, is known since the first Civil Codes of Western countries as: in the French Civil Code (Articles 1372 -1375), in the Italian Civil Code (Articles 2028-2032), the Croatian Law "On Obligations" (Articles 221-225), the Swiss Law "On Obligations", etc. The former socialist countries did not recognize it as a legal institute. The common denominator of these mentioned legislations is in the first place that, the expansion of foreign works or actions can be undertaken, when it is necessary and when the interested (competent) is absent, otherwise the extender will be responsible for the damage of case (Gjata, 2010). The perpetration of another's work or interests must be distinguished from the order. The latter arises based on a contractual relationship. The customer, as a rule, acts in his own name and on behalf of the customer, but with the knowledge and according to his order. In the perpetration for the benefit of the other, the perpetrator acts without the knowledge and approval of the other. Only after learning of its approval, the relationship of the order is established. Similar to the order is, when the perpetrator acts in his own name, gaining rights by assuming obligations to third parties (Gjata, 2010).

This is similar to enrichment without cause, as even in the latter we have to do with avoiding the reduction of wealth, but the most important is the difference between them: in enrichment without cause, the enrichment of one party is to the detriment of the other. However, this enrichment is not intentional, because it is the result of various mistakes, in the first place by the one whose wealth has been reduced. In acting on behalf of another without being authorized, the beneficiary is obliged to pay the necessary expenses to the perpetrator (Gjata, 2010).

These institutes fall into the category of unilateral legal actions that bring certain effects, noncontractual obligations of other persons. Acting on behalf of another without being authorized differs from other unilateral legal actions, more for its features dissimilar to those of other actions (Gjata, 2010).

\section{Conclusions}

After elaborating and analyzing this legal institute of obligations, in this paper regarding the perpetration of the work of another without consent as a material source of the law of obligations in Kosovo, we came to the conclusion that; the perpetration of foreign affairs without consent or management without order, known in Roman Law sinegotiorum gestio, today in our law is a special source of the law of obligations. It was identified that this source of obligations, exists when someone perpetrates the work of another without consent. The one who does the work is the gestor, while the one to whom the work is done is the principal. So, in this type of obligation, someone's work must be perpetrated because there is a certain need, by which the contractor performs his constitutional duty without consent. However, we noticed that the work should not be done at all costs, but only in those cases when certain conditions and circumstances are met. This foreign work had to be done because there was a need, or that the work to be done was beneficial to the principal even though it might be illegal.

It was also seen that in Roman law this institute of obligations was part of quasi contractus (quasi contracts). We also noticed that the naming of this source in the law of obligations is based on 
the fact that, in this material source of obligations we have to do with the relationship of obligations caused between a person who has performed a job instead of another person on his behalf and without his consent. We also saw that in this legal institute of obligations we are dealing with taking active actions in foreign property and in the protection of that property, without prior receipt of the order by its holder. It was noticed that the subject who performs the work for the other without his consent, is called the perpetrator of the work of another without consent, uninvited, manager, the gestor (negatiorum gestor), while the person on whose behalf the work is done is called: the principal (dominus negoti). The uninvited performer of foreign affairs, according to the rules, is presented as a creditor, who has the right to request the principal as a debtor, to pay the expenses, which were committed by the perpetrator of the work of another without consent.

We also noticed that the perpetration of the work of another should be clearly distinguished from unjust enrichment because in the perpetration of the work of another without consent we have to do with trespassing in one's wealth and that wealth should be preserved or increased, while unjust enrichment is about increasing one's wealth at the expense of another's wealth and therefore there was no basis of reasoning. Also, the perpetration of the work of another without consent must be distinguished from the order because the latter arises on the basis of a contractual relationship, where with this contract the customer usually acts on his own name and on behalf of the customer, but with the acknowledgement and at the request of the customer.

We saw that, in this source of the law of obligations, certain legal effects are created between the gestor (negatiorum gestor) and the principal (dominus negoti).

In conclusion, we can say that the rules of perpetration of the work of another without consent should not be equated with other rules of the institutions of Law of Obligations, because perpetrating of the work of another without consent has its own special rules within of the law of obligations and the Law on Obligations in the Republic of Kosovo.

\section{References}

Alishani, A, (1989), Law of Obligations, General Part, Prishtina.

Berisha, R, (2013), Commentary on the Law on Obligations, Book I, Prishtina.

Borkowski, A \& Du Plessis, P, (2004), Roman Law, UET Press, Tirana.

Civil Code of France, 1804, Dalloz, Paris, 1985 and 2002

Dauti, N, (2008), Law of Obligations, General Part, Prishtina.

Dauti, N, (2016), Law of Obligations, General Part, Prishtina.

Gjata, Rr, (2010), Non-Contractual Obligations, "Muza”, Tirana / Republic of Albania.

Italian Civil Code, (2006) with comments by Tramontano.

Law on Obligations (Law. No. o4 / L-o77), Official Gazette of the Republic of Kosovo, No. 16/19 dated 19.06.2012. Legier, G, (2008), Civil Law, Obligations, Papyrus, Tirana / Republic of Albania.

Loza, B, (1978), Obligaciano Pravo, Opsti deo, Sarajevo.

Milosevic, L, (1977), Law of Obligations, General Part, Prishtina.

Mustafaj, I, (2016), Obligations and Contracts, Aron Print, Tirana.

Puhan, I, (1968), Roman Law, ETMM, Prishtina.

Radisic, J, (1980), Obligacije i obligacioni odnosi, Glasnik Pravnog Fakulteta,Kragujevac.

Sallabanda, A, (1961), The Law of Obligations, Tirana / Republic of Albania.

The Civil Code of the Republic of Albania, approved by law No.785o, dated 29.7.1994, amended by law No.8536, dated 18.10.1999, law No.8781, dated 3.5.2001 and law No.17 / 2012

Tutulani- Semini, M, (2016), Law of Obligations and Contracts, General Part and Special Part, Real Stamp, Tirana.

Vokshi, A, (2015), Handbook for preparing for the bar exam, Prishtina.

Zimmerman, R, (1996), The law of obligations, Oxford University Press. 